Volume 1 Issue 2 (2017) Pages $131-138$

Jurnal Obsesi : Jurnal Pendidikan Anak Usia Dini

DOI: $10.31004 /$ obsesi.v1i2.23

\title{
Pengaruh Musik dalam Mengembangkan Kemampuan Mengenal Bilangan Siswa Kelompok A di TK Lintang Surabaya
}

\author{
Isabella Hasiana ${ }^{1 凶}$ Aniek Wirastania ${ }^{2}$ \\ Universitas PGRI Adi Buana Surabaya
}

\begin{abstract}
Abstrak
Pemahaman konsep bilangan merupakan sesuatu yang sangat penting khususnya bagi anak usia dini. Hal ini dikarenakan bilangan selalu kita gunakan sepanjang proses kehidupan. Selain itu memahami bilangan merupakan langkah awal dari pelajaran matematika, tanpa pemahaman akan bilangan, maka seorang anak akan mengalami kesulitan dalam tahapan pembelajaran selanjutnya. Penelitian ini bertujuan untuk mengembangkan kemampuan mengenal bilangan siswa kelompok A melalui program bimbingan menggunakan media musik. Dengan menggunakan metode penelitian quasi experimental design (eksperimen semu). Penggunaan metode quasi experimental design dilakukan agar dapat mencapai tujuan penelitian. Desain quasi eksperimen yang digunakan dalam penelitian ini adalah nonequivalen pretest-posttest control group design yang dilakukan dalam uji lapangan program bimbingan menggunakan media musik dalam meningkatkan kemampuan mengenal bilangan pada anak Kelompok A di TK Lintang Surabaya . Hasil penelitian ini dianalisa dengan rumus Uji T yang dilakukan menggunakan bantuan program SPSS. Berdasarkan hasil penelitian yang dilakukan diperoleh dengan sig $(0,000)<0,05$ yang berarti ada perbedaan antara kelompok eksperimen dengan kelompok kontrol dalam mengenal lambang bilangan dengan menggunakan musik. Maka dapat disimpulkan bahwa program bimbingan dengan menggunakan media musik yang telah disusun dapat dikatakan memiliki pengaruh dalam meningkatkan kemampuan mengenal bilangan pada anak kelompok A
\end{abstract}

Kata Kunci : Anak Usia Dini, Bilangan, Musik

\begin{abstract}
Understanding the concept of numbers is something that is especially important for young children. This is because the numbers we always use throughout the life process. Also understanding numbers is the first step of a mathematics lesson, without an understanding of numbers, then a child will have difficulty in the next stage of learning. This study aims to develop the ability to recognize the number of students of group A through guidance program using music media. Using quasi-experimental design used in this research is non-equivalent pretest-posttest control group design which is done in field test of guidance program using music media in increasing the ability to recognize the number in child of Kindergarten Group A at Lintang Kindergarten. The result of this research is analyzed by T test formula which is done using help SPSS program. Based on the results of research conducted obtained with sig $(0,000)<0.05$ which means there is a difference between the experimental group with the control group in recognizing the number symbols by using music. So it can be concluded that the guidance program by using music media that has been compiled can be said to have an effect in improving the ability to recognize the numbers in children group A.
\end{abstract}

Keywords : Early Childhood, Number, Music

@ Jurnal Obsesi Prodi PG-PAUD FIP UPTT 2017

$\triangle$ Corresponding author :

Address : Surabaya, Indonesia

Email : isabella@unipasby.ac.id

ISSN 2356-1327 (Media Cetak)

ISSN 2549-8959 (Media Online) 


\section{PENDAHULUAN}

Dalam kehidupan, manusia selalu membutuhkan pendidikan. Pendidikan yang diperoleh merupakan upaya bagi manusia untuk mengembangkan potensi dirinya melalui proses pembelajaran dan/atau dengan cara lain yang dikenal dan diakui oleh masyarakat. Dengan arti lain, manusia juga memiliki kemampuan untuk mengembangkan potensi yang ada dalam dirinya menjadi lebih optimal.

Nurihsan, Juntika \& Yusuf, Syamsu. (2009). berpendapat bahwa kemampuan adalah suatu bentuk pertumbuhan atau perubahan dalam diri seseorang yang dinyatakan dalam cara-cara bertingkah laku yang baru setelah mendapatkan pengalaman dan latihan. Perubahan tingkah laku baru yang terjadi dalam diri individu contohnya adalah pemahaman dari pengertian-pengertian baru, perubahan dalam menyingkapi suatu kondisi, dari tidak tahu menjadi tahu, memiliki keterampilan, memiliki kesanggupan dalam menghargai perkembangan sifat-sifat sosial, emosional, dan pertumbuhan jasmani.

Anak usia dini memiliki aspek perkembangan yang perlu dikembangkan. Aspek perkembangan tersebut antara lain, aspek motorik kasar dan motorik halus, aspek bahasa, aspek kognitif, aspek sosial emosi anak. Menurut Undang-Undang No 20 Tahun 2003 tentang Sistem Pendidikan Nasional menyatakan bahwa Pendidikan anak usia dini adalah suatu upaya yang ditujukan kepada anak sejak lahir sampai dengan usia enam tahun yang dilakukan melalui pemberian rangsangan pendidikan dan membantu pertumbuhan dan perkembangan jasmani dan rohani agar anak memiliki kesiapan dalam memasuki pendidikan lebih lanjut.

Selain itu sejalan dengan Peraturan Menteri Pendidikan Nasional Republik Indonesia Nomor 58 Tahun 2009 yang menegaskan juga bahwa tujuan pendidikan taman kanak-kanak adalah membantu anak didik untuk dapat mengembangkan potensi yang ada dalam dirinya baik secara psikis maupun fisik yang meliputi perkembangan nilai agama dan moral, perkembangan fisik motorik, perkembangan kognitif, perkembangan bahasa serta perkembangan sosial emosional.

Berdasarkan observasi awal yang dilakukan peneliti terhadap anak Taman Kanak-Kanak kelompok A di TK Lintang, menemukan bahwa kelompok A memiliki kekurangan dalam memahami tentang konsep bilangan.

Pemahaman konsep terhadap suatu bilangan merupakan hal yang penting dan mendasar khususnya bagi anak usia dini. Secara intelektual, anak masih belum mengerti tentang konsep bilangan. Namun mereka sudah memiliki pengertian tersebut secara intuitif dan perlahan dituntun menuju kepada suatu pemahaman intelektual secara simbolik.

Bilangan selalu kita gunakan di dalam kehidupan sehari-hari. Memahami bilangan pada dasarnya merupakan langkah awal dari pelajaran matematika. Karena, tanpa pemahaman tentang bilangan maka akan kesulitan dalam tahapan pembelajaran selanjutnya.

Anak usia dini cenderung memiliki minat terhadap bilangan yang cukup besar. Hal ini dikarenakan, didalam kehidupan sehari-hari, berbagai bentuk bilangan sering ditemui oleh anak. Misalnya, pada jam dinding, kalender, pohon berhitung, nomor rumah, bahkan bilangan pada kue ulang tahun.

Bilangan berkaitan dengan nilai yang mewakili banyaknya suatu benda sedangkan lambang bilangan merupakan notasi tertulis dari sebuah bilangan. Lambang bilangan merupakan sebuah simbol yang mewakili nilai dari suatu bilangan (Supadmi, 2012).

Bilangan adalah suatu konsep matematika yang digunakan untuk pencacahan dan pengukuran. Simbol ataupun lambang bilangan yang mewakili suatu bilangan disebut sebagai angka atau lambang.

Proses belajar mengajar bilangan harus memperhatikan karakterisitik matematika. Seperti yang disampaikan oleh Astuti (2016) ada beberapa karakteristik matematika, yaitu materi matematika menekankan penalaran yang bersifat deduktif, materi matematika 
bersifat hierarkis dan terstruktur serta dalam mempelajari matematika dibutuhkan ketekunan, keuletan, serta memiliki rasa cinta terhadap matematika.

Oleh sebab itu, dalam mempelajari matematika perlu belajar dahulu tentang konsep matematika yang mempunyai daya bantu terhadap konsep matematika yang lain (Astuti, 2016).

Belajar bilangan bagi anak usia dini bukan berarti belajar yang menuntut anak untuk mampu berhitung sampai seratus, seribu, atau bahkan menuntut anak untuk memahami operasi matematika yang rumit. Belajar bilangan untuk anak usia dini,lebih kepada pengenalan konsep bilangan dan simbol dari suatu bilangan. Belajar bilangan pada anak usia dini masih dalam proses mengenal bilangan dimana bukan hanya mengenal bentuk dari bilangan itu namun juga mengenal makna bilangan tersebut (Apriliani, 2013).

Kemampuan mengenal lambang bilangan merupakan kemampuan dasar yang harus dikuasai oleh anak. Hal ini merupakan modal awal bagi anak untuk mengenal hal-hal penting dalam kehidupan sehari-hari khususnya yang berhubungan dengan bilangan. Anak mampu mengenal waktu atau jam, tanggal, bulan, serta tahun yang semuanya itu berhubungan dengan bilangan.

Anak dikatakan mengenal lambang bilangan yang baik apabila ia tidak hanya sekedar menghafal namun telah mengenal bentuk dan makna dari bilangan tersebut dengan baik.

Depdiknas (2007) mengemukakan bahwa ciri-ciri yang menandai bahwa anak usia dini mulai menyenangi pembelajaran membilang antara lain, a). secara spontan telah menunjukkan ketertarikan pada aktivitas pembelajaran dengan bilangan; b). anak mulai menyebutkan urutan bilangan tanpa pemahaman; c). anak mulai menghitung benda yang ada disekitarnya secara spontan; d). anak mulai membanding-bandingkan benda-benda dan peristiwa yang ada disekitarnya; e). anak mulai menjumlah-jumlahkan atau mengurangi angka dan benda yang ada disekitarnya tanpa disengaja.
Pengenalan dini tentang konsep bilangan perlu dilakukan sejak dini untuk menjaga agar tidak terjadi masalah kesulitan belajar karena belum menguasai konsep berhitung. Karena, ada banyak kasus dimana berhitung di jalur matematika merupakan suatu hal yang menakutkan.

Berdasarkan pengamatan yang peneliti temukan di lapangan, tepatnya dalam proses pembelajaran, terlihat anak kurang memahami konsep sederhana dalam kehidupan sehari-hari terutama dalam kemampuan mengenal bilangan. Anak kurang mampu dalam menghubungkan antara konsep bilangan dengan lambang bilangan, mengurutkan dan memasangkan jumlah benda dengan angka. Hal ini disebabkan karena guru cenderung menuntut anak untuk menyebutkan bilangan secara hafalan. Selain itu media yang digunakan masih sederhana dan belum ada pengembangan sehingga proses pembelajaran terkesan monoton.

Pengenalan lambang bilangan ini dibutuhkan adanya suatu bentuk aktivitas belajar yang aktif, kreatif dan menyenangkan. Hal ini dilakukan agar anak dalam belajar merasa senang dan tidak jenuh sehingga hasil belajar anak bisa seoptimal mungkin. Pengenalan lambang bilangan bermanfaat untuk meningkatkan daya pikir serta kreativitas anak. Selain itu melalui aktivitas mengenal bilangan juga mampu mendorong anak membuat suatu inovasi besar, kepekaan anak menjadi meningkat terhadap suatu obyek yang dilihatnya, sehingga anak juga akan mampu membedakan dan menganalisa (Pradana, 2016).

Untuk membantu anak dalam mengenal bilangan maka diperlukan suatu media. Hal ini dikarenakan salah satu prinsip pembelajaran bagi anak usia dini yaitu belajar melalui media. Penggunaan media yang sesuai untuk anak usia dini terutama dalam mengenalkan bilangan memiliki peranan yang sangat besar. Anak tidak hanya diajarkan konsep bilangan yang berbentuk abstrak, namun juga berbentuk konkrit, sehingga mudah 
dipahami dan dimengerti oleh anak. Selain itu, dengan adanya media yang menarik, anak juga memiliki motivasi yang ditunjukkan dengan perasaan senang, terangsang dan tertarik sehingga mendorong anak untuk berfikir positif terhadap pembelajaran mengenal bilangan.

Menurut Payne (Coupley, 2001) indikator dalam mengenal bilangan dan operasi bilangan adalah sebagai berikut ini: a). Counting adalah kemampuan untuk menyebutkan bilangan secara urut dari satu, dua, tiga, dan seterusnya sampai anak bisa mengingatnya; b).One to one correspondence adalah hubungan satu kesatuan yang merupakan kemampuan yang dimiliki anak untuk bisa mengurutkan , menyesuaikan jumlah angka dengan benda. Contohnya anak bisa memahami bahwa ada sebuah pensil maka dia akan mengatakan satu pensil; c). Quantity atau kuantitas adalah kemampuan yang dimiliki anak untuk mengetahui jumlah benda yang ada didepannya dengan cara menghitung secara urut benda tersebut.

Kemampuan mengenal lambang bilangan anak akan berkembang sesuai dengan tingkatan pencapaian perkembangan yang terdapat dalam Permendiknas No. 58 Tahun 2009 yaitu anak mampu mengenal lambang bilangan 1-10, apabila pengenalan lambang bilangan dilakukan dalam suasana yang menyenangkan. Untuk mengembangkan kemampuan mengenal bilangan tersebut digunakan media pembelajaran yang aktif dan menyenangkan bagi anak, yaitu dengan media musik.

Musik yang digunakan sebagai media pembelajaran tentunya harus dapat membuat suasana belajar menjadi menyenangkan dan tidak membosankan. Dalam hal ini musik yang berkaitan dengan bilangan.

Penggunaan musik kepada anak tentu akan membawa dampak positif bagi proses pembelajarannya. Hal ini dikarenakan musik merupakan salah satu cara untuk merangsang pikiran, sehingga anak dapat menerima materi dengan baik. Selain itu dengan musik akan merangsang pikiran, memperbaiki konsentrasi, ingatan, meningkatkan aspek kognitif, fisiologis dan juga kecerdasan emosional. Musik juga akan mempengaruhi perasaan anak yang akan berpengaruh pada proses belajar mengajar.

Berdasarkan hasil amatan di lapangan, maka dapat dirumuskan suatu permasalahan yaitu bagaimana musik dapat mengembangkan kemampuan mengenal bilangan anak di Taman KanakKanak kelompok A. Dalam hal ini, peneliti dan guru mengupayakan suatu media pembelajaran yaitu mengenalkan bilangan dengan musik. Sehingga tujuan yang ingin dicapai dalam penelitian ini yaitu untuk mengembangkan kemampuan mengenal bilangan dengan menggunakan media musik bagi anak taman kanak-kanak kelompok A.

\section{METODE PENELITIAN}

Penelitian ini dilaksanakan dengan menggunakan pendekatan kuantitatif. Metode yang digunakan dalam penelitian ini adalah quasi experimental design (eksperimen semu). Penggunaan metode quasi experimental design dilakukan agar dapat mencapai tujuan penelitian yaitu meningkatkan kemampuan mengenal bilangan pada anak TK Kelompok A.

Desain quasi eksperimen yang digunakan dalam penelitian ini adalah nonequivalen pretest-posttest control group design (Sugiyono, 2011). Gambaran alur pelaksanaan program bimbingan menggunakan media musik dapat dilihat dalam gambar sebagai berikut.

\section{Tabel 1}

Desain Penelitian

\begin{tabular}{|c|c|c|c|}
\hline Kelompok & $\begin{array}{c}\text { Pre- } \\
\text { test }\end{array}$ & $\begin{array}{c}\text { Pelaksanaan } \\
\text { Program }\end{array}$ & $\begin{array}{c}\text { Post- } \\
\text { test }\end{array}$ \\
\hline Eksperimen & $\mathrm{O}_{1}$ & $\mathrm{X}_{1}$ & $\mathrm{O}_{2}$ \\
\hline Kontrol & $\mathrm{O}_{1}$ & $\mathrm{X}_{2}$ & $\mathrm{O}_{2}$ \\
\hline
\end{tabular}

Keterangan :

$$
\begin{aligned}
0_{1} & \text { : tes awal (sebelum diberikan } \\
& \text { perlakuan) pada kelompok } \\
& \text { eksperimen dan kelompok kontrol } \\
0_{2} & \text { : tes akhir (setelah diberikan } \\
& \text { perlakuan) pada kelompok } \\
& \text { eksperimen dan kelompok kontrol }
\end{aligned}
$$


$\mathrm{X}_{1}$ : pemberian perlakuan dengan menggunakan media musik

$\mathrm{X}_{2}$ : perlakuan konvensional/tanpa perlakuan

Berdasar pada rancangan kuasi eksperimen diatas, maka uji keefektifan media musik dapat diuraikan dalam bagan berikut.

\section{Gambar 1}

\section{Rancangan Perlakuan Kuasi} Eksperimen
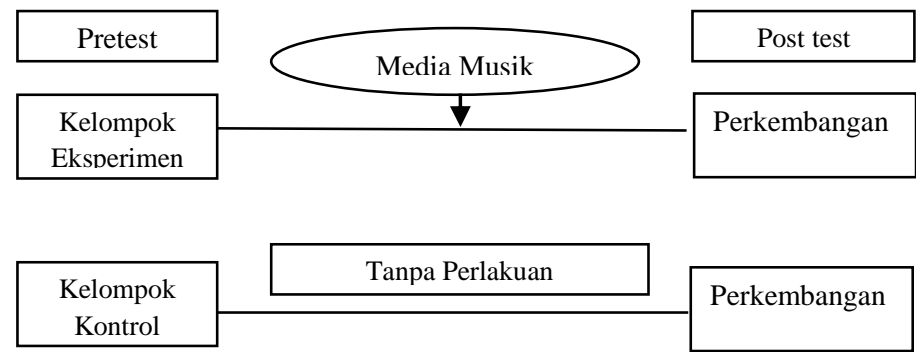

Sampel dalam penelitian ini adalah salah satu Taman Kanak-Kanak yang dibatasi pada kelompok A dan berada di kota Surabaya sejumlah 30 siswa untuk kelompok eksperimen dan 28 siswa untuk kelompok kontrol.

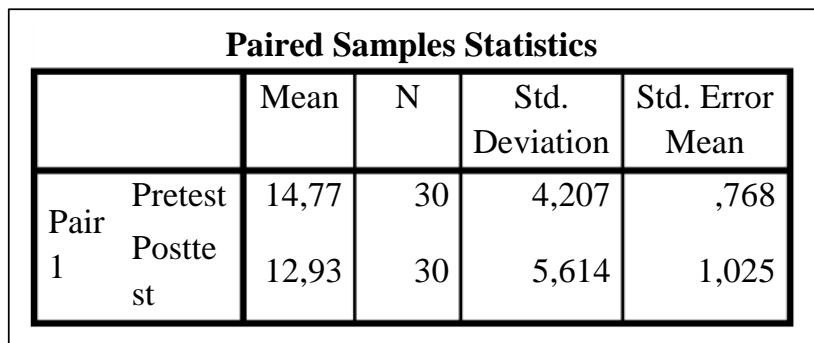

yang dilakukan dengan memberikan test kepada siswa untuk mengetahui kemampuan mereka dalam mengenal lambang bilangan. Indikator yang digunakan adalah sebagai berikut :

Tabel 2

Perilaku Amatan Kemampuan Mengenal Bilangan

\begin{tabular}{|l|l|l|l|}
\hline \multicolumn{1}{|c|}{ Perilaku Amatan } & SM & M & BM \\
\hline $\begin{array}{l}\text { Anak mampu menyebutkan } \\
\text { bilangan secara berurutan }\end{array}$ & & & \\
\hline $\begin{array}{l}\text { Anak mampu memasangkan } \\
\text { angka dengan jumlah benda }\end{array}$ & & & \\
\hline $\begin{array}{l}\text { Anak mampu menghitung } \\
\text { jumlah benda secara } \\
\text { berurutan }\end{array}$ & & & \\
\hline
\end{tabular}

Keterangan :

SM : Sangat Mampu

M : Mampu

BM : Belum Mampu

Metode analisis data yang digunakan dalam penelitian ini menggunakan rumus Uji $\mathrm{T}$ dengan penghitungan dibantu program SPSS.

Alat yang digunakan dalam penelitian ini adalah lagu atau musik yang berkaitan dengan bilangan. Pada kelompok eksperimen, akan diberikan perlakuan sebanyak 6 kali untuk melihat keefektifan media musik ini dalam kemampuan mengenal bilangan. Sedangkan pada kelompok kontrol, proses pembelajaran dilakukan secara konvensional dan tidak ada perubahan dalam penggunaan media.

\section{HASIL DAN PEMBAHASAN}

Dari hasil penelitian yang telah dilakukan kepada kelompok kontrol, setelah diberikan pretest dan kemudian kelompok kontrol melakukan pembelajaran konvensional sebanyak 6 kali pertemuan dan diberikan posttest, dapat dilihat dari hasil dibawah ini:

Paired Samples Correlations

\begin{tabular}{|ll|r|r|r|}
\hline & N & $\begin{array}{c}\text { Correlati } \\
\text { on }\end{array}$ & Sig. \\
\hline $\begin{array}{l}\text { Pair } \\
1\end{array}$ & $\begin{array}{l}\text { Pretest \& } \\
\text { Posttest }\end{array}$ & 30 &, 272 &, 145 \\
\hline
\end{tabular}

Paired Samples Test

\begin{tabular}{|c|c|c|c|c|c|c|c|c|c|}
\hline & & \multicolumn{5}{|c|}{ Paired Differences } & \multirow{3}{*}{$\mathrm{t}$} & \multirow{3}{*}{ df } & \multirow{3}{*}{$\begin{array}{l}\text { Sig. (2- } \\
\text { tailed) }\end{array}$} \\
\hline & & \multirow[t]{2}{*}{ Mean } & \multirow[t]{2}{*}{$\begin{array}{l}\text { Std. } \\
\text { Deviatio } \\
\mathrm{n}\end{array}$} & \multirow[t]{2}{*}{$\begin{array}{l}\text { Std. } \\
\text { Error } \\
\text { Mean }\end{array}$} & \multicolumn{2}{|c|}{$\begin{array}{l}95 \% \text { Confidence } \\
\text { Interval of the } \\
\text { Difference }\end{array}$} & & & \\
\hline & & & & & Lower & Upper & & & \\
\hline Pair 1 & $\begin{array}{l}\text { Pretest - } \\
\text { Posttest }\end{array}$ & 1,833 & 6,029 & 1,101 &,- 418 & 4,085 & 1,666 & 29 & ,107 \\
\hline
\end{tabular}


Dari hasil penghitungan di atas yang dilakukan terhadap kelompok kontrol, menyimpulkan bahwa sig $(0,107)$ $>0,05$ maka Ho diterima. Artinya tidak ada perbedaan pada kelompok ini. Pada kelompok kontrol, pembelajaran mengenal bilangan tidak menggunakan media musik. Siswa belajar dengan model pembelajaran yang biasa dilakukan sehari-hari.

Sedangkan pada kelompok eksperimen, Dari hasil penghitungan yang telah dilakukan, dapat diartikan bahwa sig $(0,000)<0,05$ yang berarti ada perbedaan dalam pengenalan angka dengan menggunakan media musik. Pada kelompok eksperimen, pembelajaran mengenal bilangan dilakukan dengan media musik. Dalam hal ini ada perbedaan sebelum dan sesudah perlakuan. Siswa lebih mudah untuk mengenal dan mengerti tentang konsep bilangan. Hasil penghitungan tampak dalam tabel dibawah ini:

Paired Samples Statistics

\begin{tabular}{|ll|c|r|r|r|}
\hline & Mean & $\mathrm{N}$ & $\begin{array}{c}\text { Std. } \\
\text { Deviatio } \\
\mathrm{n}\end{array}$ & $\begin{array}{c}\text { Std. } \\
\text { Error } \\
\text { Mean }\end{array}$ \\
\hline $\begin{array}{l}\text { Pair } \\
1\end{array}$ & $\begin{array}{l}\text { Pretest } \\
\text { Pt }\end{array}$ & 15,27 & 30 & 3,999 &, 730 \\
\hline
\end{tabular}

Paired Samples Correlations

\begin{tabular}{|cc|c|c|c|}
\hline & $\mathrm{N}$ & $\begin{array}{c}\text { Correlatio } \\
\mathrm{n}\end{array}$ & Sig. \\
\hline $\begin{array}{c}\text { Pair } \\
1\end{array}$ & $\begin{array}{c}\text { Pretest \& } \\
\text { Posttest }\end{array}$ & 30 &, 333 &, 072 \\
\hline
\end{tabular}

Perbandingan antara kelompok kontrol dan kelompok eksperimen dilakukan untuk melihat pengaruh media musik dalam mengembangkan kemampuan mengenal bilangan pada anak kelompok A. Hal tersebut terlihat dari tabel dibawah ini:

Paired Samples Statistics

\begin{tabular}{|cc|c|c|c|c|}
\hline & Mean & $\mathrm{N}$ & $\begin{array}{c}\text { Std. } \\
\text { Devia } \\
\text { tion }\end{array}$ & $\begin{array}{c}\text { Std. Error } \\
\text { Mean }\end{array}$ \\
\hline Pair 1 & $\begin{array}{l}\text { Kontrol } \\
\text { Eksperi } \\
\text { men }\end{array}$ & 12,93 & 30 & 5,614 & 1,025 \\
\hline
\end{tabular}

Paired Samples Correlations

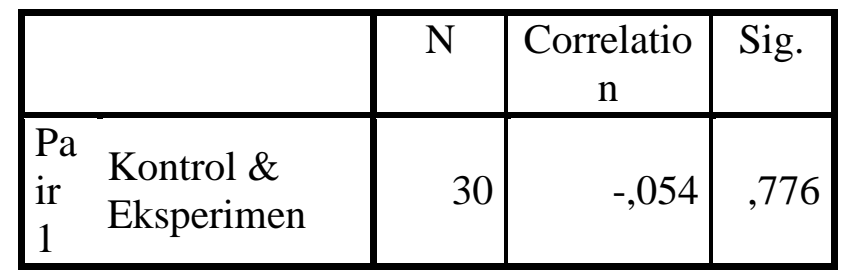

Dari hasil penghitungan yang telah dilakukan terhadap kelompok kontrol dan kelompok eksperimen, bahwa sig $(0,000)<$ 0,05 maka dapat dikatakan ada perbedaan antara kelompok kontrol dan kelompok eksperimen dalam pengenalan bilangan dengan menggunakan media musik.

Kemampuan anak dalam menyebutkan urutan bilangan 1 - 10 atau tahap accounting merupakan tahapan yang paling mudah dari kemampuan anak untuk mengenal bilangan. Sriningsih (2008) menyatakan bahwa kegiatan berhitung untuk anak usia dini disebut juga sebagai kegiatan menyebutkan urutan bilangan atau membilang buta. Berhitung dalam hal ini yaitu menyebutkan urutan bilangan dengan menghafal secara lisan tanpa mengaitkan dengan benda konkrit. Media musik membantu untuk memudahkan anak dalam menyebut urutan bilangan tidak hanya sekedar menghafal. Tetapi mereka benar-benar mengerti arti dari bilangan tersebut. Selain itu, adanya faktor pengulangan juga memiliki peran dalam meningkatkan kemampuan anak.

Proses pembelajaran yang menggunakan media lebih berjalan dengan optimal dibandingkan dengan metode pembelajaran yang klasikal. Media merupakan salah satu hal yang mendukung dalam pengenalan bilangan kepada anak khususnya anak usia dini.

Peran media dalam pembelajaran merupakan segala sesuatu yang dapat digunakan untuk menyalurkan pesan pengirim kepada penerima, sehingga dapat merangsang pikiran, perasaan, perhatian dan minat belajar siswa yang nantinya akan mengarah kepada terjadinya proses belajar

(https://witarafianti.wordpress.com/2016/0 4/21/media-yang-digunakan-dalam-prosesbelajar-bimbingan-konseling-anak-disekolah/). 
Pemanfaatan musik dalam pembelajaran ini dapat membuat proses belajar menjadi menyenangkan. Sebagian besar anak di dunia senang mendengarkan musik. begitu mendengar musik, anak pada umumnya akan menggerakkan badannya mengikuti irama musik. Anak menjadi tertarik dan tidak bosan terutama berkaitan dengan pengenalan angka. Selain itu, dengan menggunakan media musik, anak juga lebih mudah mengingat bilangan karena dalam media yang digunakan ini, ada pengulangan-pengulangan yang semakin menguatkan pembelajaran mengenal bilangan. Proses pembelajaran yang dilakukan seraya bermain membuat anak menjadi lebih tertarik dan tidak mudah bosan.

Bagi anak usia dini, bermain merupakan kegiatan yang dilakukan sepanjang hari dan dengan bermain anak dapat belajar tentang apa yang ingin mereka ketahui dan pada akhirnya mampu untuk mengenal semua peristiwa yang terjadi di sekitarnya tanpa merasa tertekan.

Dari kegiatan bermain menggunakan media musik, anak memperoleh pengamalan dalam mengenal bilangan. Musik menjadi media perantara pemahaman anak terhadap sifat bilangan yang abstrak menjadi konkrit. Hal ini senada dengan pendapat dari Sriningsih (2008) yang menyatakan, bahwa anak memahami konsep bilangan melalui pengalaman bekerja dan bermain langsung dengan benda-benda konkrit.

Kemampuan mengenal bilangan merupakan hal yang penting untuk dipelajari khususnya pada anak usia dini. Dikarenakan pada dasarnya setiap anak memerlukan bilangan karena bilangan merupakan bagian integral dari kehidupan.

Pada kelompok eksperimen dan kelompok kontrol, dapat terlihat jelas perbedaan bahwa siswa yang berada dalam kelompok eksperimen lebih cepat menguasai dan hafal tentang bilangan dibandingkan dengan kelompok kontrol. Mengenal lambang bilangan merupakan proses yang sangat penting untuk dikembangkan dikarenakan merupakan dasar kemampuan matematika pada anak.
Kemampuan mengenal lambang bilangan yang baik sejak anak usia dini akan memudahkan bagi anak untuk memahami operasi bilangan pada tingkat pendidikan selanjutnya. Anak dikatakan mengenal lambang bilangan dengan baik apabila tidak hanya sekedar menghafal lambang bilangan, namun mereka juga mengenal bentuk makna dari bilangan tersebut dengan baik. Pemberian perlakuan diberikan sebanyak 6 kali. Pada kelompok eksperimen, dari 30 siswa sebelum ada pemberian perlakuan dengan menggunakan media musik, sebanyak 23 siswa masih belum mengenal lambang bilangan dengan baik. Mereka hanya bisa menghafal secara berurutan. Saat lambang bilangan diacak, mereka belum mengenal bentuk dan makna lambang bilangan tersebut. Hal ini berarti, penggunaan media yang menarik juga sangat mendukung belajar siswa.

Pada kelompok kontrol, kurangnya kemampuan anak mengenal lambang bilangan 1 - 10 dikarenakan pembelajaran yang dilakukan hanya sebatas anak ditunjukkan lambang bilangan dan diminta untuk mencari gambar yang sesuai dengan lambang bilangan tersebut. dari 28 siswa, hanya ada 6 siswa yang mengenal lambang bilangan dengan baik. Hal ini dikarenakan, mereka sudah dikenalkan dengan lambang bilangan oleh orangtua sebelum masuk TK.

Dari perbandingan kedua kelompok tersebut, pembelajaran yang dilakukan dengan menggunakan media musik membuat anak lebih tertarik sehingga dapat meningkatkan perhatian dan keaktifan anak dalam bermain sambil belajar.

Anak usia 4-5 tahun memiliki tingkat perkembangan kognitif yang berada pada tahap pra operasional, hal ini berarti anak sudah mampu untuk menggunakan simbol-simbol dalam pikiran untuk mempresentasikan bendabenda atau kejadian (Sujiono, 2007).

\section{KESIMPULAN}

Berdasarkan hasil penelitian yang dilakukan diperoleh dengan sig $(0,000)<$ 
0,05 yang berarti ada perbedaan antara kelompok eksperimen dengan kelompok kontrol dalam mengenal lambang bilangan dengan menggunakan musik. Maka dapat disimpulkan bahwa media musik memiliki pengaruh dalam meningkatkan kemampuan mengenal bilangan pada anak kelompok A.

Anak sudah bisa menyebutkan nama-nama dari angka-angka, selanjutnya mengetahui jumlah benda dari angkaangka tersebut untuk kemudian dikenalkan lambang bilangannya yang dilakukan secara berulang-ulang dengan bantuan musik.

Suasana pembelajaran yang dilakukan dengan bermain mampu menghadirkan suasana belajar yang menyenangkan dan membuat anak mampu menyerap apa yang dipelajari menjadi lebih optimal.

Berdasarkan hasil penelitian yang telah dilakukan, maka dapat disarankan untuk tetap melaksanakan pembelajaran mengenal bilangan $1-10$ dengan menggunakan media musik. Hal ini juga dapat dilakukan untuk mengenalkan bilangan $11-20$.

\section{UCAPAN TERIMAKASIH}

Peneliti mengucapkan terimakasih kepada seluruh pihak yang telah membantu pelaksanaan penelitian ini, yaitu kepada:

1. Kepala TK Lintang Surabaya beserta Guru dan Karyawan

2. Ketua Program Studi PG-PAUD Universitas PGRI Adi Buana Surabaya

3. Kepada seluruh pihak yang tidak dapat disebutkan satu persatu

\section{DAFTAR PUSTAKA}

Astuti. 2016. Peningkatan Kemampuan Anak Mengenal Konsep Bilangan Melalui Permainan Kartu Angka di Kelompok B TK Aisyiyah Pulau Payung Kecamatan Rumbio Jaya. Jurnal PGPAUD STKIP PTT Volume 2 Nomer 1 Tahun 2016 Halaman 90-99.

Apriliani, 2013. Penerapan Model Number Head Together Dengan Media
Dadu Untuk Meningkatkan

Kemampuan Mengenal

Konsep Bilangan. Fakultas Ilmu Pendidikan. Universitas Pendidikan

Ganesha. Singaraja

Coupley. 2001. The Young Child and Matematics. National Associacion for the Education of Young Children.

Depdiknas. 2007. Pedoman Pembelajaran Permainan Berhitung Permulaan di Taman Kanak-Kanak. Jakarta: Direktorat Jenderal Manajemen Pendidikan Dasar dan Menengah Direktorat Pembinaan Taman Kanak-Kanak dan Sekolah Dasar

Peraturan Menteri Pendidikan Nasional Republik Indonsia Nomor 58 Tahun 2009, tentang Standar Pendidikan Anak Usia Dini. Jakarta

Pradana 2016. Pengaruh Permainan Balok Angka Terhadap Kemampuan Mengenal Lambang Bilangan pada Anak Usia Dini. Jurnal Paud Tambusai Volume 2 Nomor 2 Halaman 8-17.

Sugiyono. (2011). Metode Penelitian Kuantitatif, Kualitatif Dan $R \& D$. Bandung: Alfabeta]

Sujiono. 2007. Metode Pengembangan Kognitif. Universitas Terbuka. Jakarta

Sriningsih. 2008. Pembelajaran Matematika Terpadu Untuk Anak Usia Dini. Pustaka Sebelas. Bandung

Supadmi. 2012. Pengembangan Kemampuan Mengenal Bilangan Melalui Penggunaan Media Lotto Angka pada Anak Kelompok B TK Pertiwi Pulosari Kebakkramat Karanganyar. $\underline{\text { Skripsi. Fakultas }}$ Keguruan dan Ilmu Pendidikan Universitas Muhammadiyah Surakarta

https://witarafianti.wordpress.com/2016/04 /21/media-yang-digunakan-dalamproses-belajar-bimbingankonseling-anak-di-sekolah/ 